\title{
A Lead (II) 3D Coordination Polymer Based on a Marine Cyclic Peptide Motif
}

\author{
Subrata Chakraborty ${ }^{1}$, Pooja Tyagi ${ }^{1}$, Dar-Fu Tai ${ }^{1{ }^{1} *}$, Gene-Hsiang Lee ${ }^{2}$ and Shie-Ming Peng ${ }^{2}$ \\ 1 Department of Chemistry, National Dong-Hwa University, Hualien 974, Taiwan \\ 2 Department of Chemistry, National Taiwan University, Taipei 106, Taiwan \\ * Author to whom correspondence should be addressed; E-Mail: dftai@mail.ndhu.edu.tw; \\ Tel.: +886-3-863-3579; Fax: +886-3-863-3570.
}

Received: 26 March 2013; in revised form: 16 April 2013 / Accepted: 24 April 2013 /

Published: 26 April 2013

\begin{abstract}
The crystal structure of a naturally occurring cyclic tetrapeptide cyclo(Gly-LSer-L-Pro-L-Glu) [cyclo(GSPE)] was obtained. The conformation of synthesized cyclo(GSPE) fixes the coordination to lead ion in a 1:1 ratio. This cyclo(GSPE)-Pb complex was constructed as an asymmetric 3D network in the crystalline state. The polymerization of a heavy metal ion with a rigid asymmetric cyclic tetrapeptide represents the first example of a new class of macrocyclic complexes.
\end{abstract}

Keywords: natural product; cyclic peptide; lead; coordination polymer; crystal structures; macrocyclic chemistry

\section{Introduction}

In the area of biomedicinal chemistry much interest has been generated in the design of metalorganic frameworks (MOFs) [1,2]. Due to their chemical variety, biocompatibility and ability to assemble spontaneously, peptides can form excellent simple nanotubes [3-5]. Some metal-peptide frameworks (MPFs) [6] have been reported, but very few of them have been characterized by crystallography [6,7]. The size and conformation of cyclic peptides [8,9] and their metal binding side chains provide a novel tool for construction of discrete metal-assembled supermolecules with unique chemical and physical properties. Cyclic tetrapeptides (CTPs) [10-15] also possess a definite inner nanocavity of a constrained nature and hence, generated highly entropic advantages in molecular recognition with the potential to confer chirality and biological activity on these compounds [16-18]. 
Compared with the $\mathrm{d}$ - and f-block metals, $\mathrm{Pb}^{2+}$ ion has a larger radius, variable coordination numbers and unique prospects for the construction of novel polymeric or multi-dimensional supramolecular networks [19-25]. The chemistry of lead has drawn a lot of interest for its wide applications in fields such as fuel additives, batteries, oil refining and paint manufacturing, but also in biological systems, where $\mathrm{Pb}$ metal has been found to interact with many amino acids, peptides and proteins: these binding preferences of $\mathrm{Pb}$ (II) have provided the inspiration for the design of a selective chelating therapy agent [26-31].

Cyclo(Gly-L-Ser-L-Pro-L-Glu) [cyclo(GSPE), 1] has metal binding sites on the side chains (serine hydroxyl and glutamic carboxylate group) and the carbonyl groups. It was first isolated from the Ruegeria strain of marine bacteria [32] and was found to possess moderate antibacterial activity against Bacillus subtilis. Its structure was elucidated on the basis of 1D and 2D NMR data, followed by the determination of absolute configuration [33]. However, a crystal structure has not been reported. Due to strain of the twelve member ring, binding to metal ions by carbonyls is more difficult than by side chains. Keeping in mind the combination of hydroxyl and carboxylato groups and from a study of natural CTPs-metal complexes, cyclo(GSPE) 1 was selected as a linking ligand to investigate the coordination chemistry of $\mathrm{Pb}(\mathrm{II})$ ion. Here the crystal structure of cyclo(GSPE) and $\{[$ cyclo(Gly-L-SerL-Pro-L-Glu) $\left.\left.\mathrm{Pb}\left(\mathrm{NO}_{3}\right)\right] \cdot 2 \mathrm{H}_{2} \mathrm{O}\right\}_{\mathrm{n}} 2$ are reported for the first time. Further $\{[c y c l o($ Gly-L-Ser-L-Pro-L$\left.\mathrm{Glu}) \mathrm{Pb}\left(\mathrm{NO}_{3}\right)\right] \cdot 2 \mathrm{H}_{2} \mathrm{O}_{3} 2$ was constructed as an asymmetric 3D network in the crystalline state. Coordination relied on the prearranged conformation of synthesized cyclo(GSPE) 1. The polymerization of a heavy metal ion with a rigid asymmetric cyclic tetrapeptide represents the first example of a new class of complexes.

\section{Results and Discussion}

\subsection{Synthesis of cyclo(GSPE) 1 and $\left\{\left[\operatorname{cyclo}(G l y-L-S e r-L-P r o-L-G l u) P b\left(\mathrm{NO}_{3}\right)\right] \cdot 2 \mathrm{H}_{2} \mathrm{O}_{n} 2\right.$}

Cyclo(GSPE) 1 was synthesized by using standard solution-phase peptide coupling protocols. Its spectral data were identical with those of natural $1[32,33]$. Crystals were prepared for the first time by slow cooling to room temperature in water. The synthesized peptide $\mathbf{1}$ was subjected to complexation with $\mathrm{Pb}$ (II). By heating an aqueous solution of the peptide 1 and the lead(II) salt in a 1:1 ratio, the $\left\{\left[\text { cyclo(Gly-L-Ser-L-Pro-L-Glu) } \mathrm{Pb}\left(\mathrm{NO}_{3}\right)\right] \cdot 2 \mathrm{H}_{2} \mathrm{O}\right\}_{\mathrm{n}} 2$ complex was obtained. Crystals were prepared by slow cooling to room temperature and resulted in a $3 \mathrm{D}$ coordination polymer. Several coordination polymers of lead with a variety of synthetic organic ligands have been reported earlier [34-38]. The structure of macrocyclic complex $\mathbf{2}$ is the first solved marine cyclo(GSPE) $\mathbf{1}$ lead complex.

\subsection{Characterization of $\left\{\left[\right.\right.$ cyclo $\left.(\mathrm{Gly}-\mathrm{L}-\mathrm{Ser}-\mathrm{L}-\mathrm{Pro}-\mathrm{L}-\mathrm{Glu}) \mathrm{Pb}\left(\mathrm{NO}_{3}\right)\right] \cdot 2 \mathrm{H}_{2} \mathrm{O}_{{ }_{n}} 2$}

NMR Spectra. Interaction between cyclo(GSPE) 1 with $\mathrm{Pb}^{2+}$ was first examined by ${ }^{1} \mathrm{H}-\mathrm{NMR}$ after reaction with $\mathrm{Pb}\left(\mathrm{NO}_{3}\right)_{2}$ (1.0 equiv) in water at $\mathrm{pH} 5.0$ and $70{ }^{\circ} \mathrm{C}$ for 4 days. The NMR spectrum of the complex 2 showed the appearance of new multiplet $(\delta=4.19-4.26)$ and triplet $(\delta=4.76)$ peaks for glutamic acid and the serine $\alpha$-protons in place of the doublet $(\delta=4.08-4.10)$ and multiplet $(\delta=4.81-4.85)$ peaks of the free peptide, respectively (Figure S3). These NMR signal changes only in the side chain protons clearly indicated their binding with $\mathrm{Pb}^{2+}$ ions outside of the cyclic peptide ring. 
Mass Spectra. MALDI-TOF mass spectrometry on the reaction product with 1.0 equivalents of $\mathrm{Pb}^{2+}$ ions showed interaction with the peptide, with peaks at $m / z 577.69,595.71$ and 719.69 corresponding to $[\mathrm{M}+\mathrm{Pb}-\mathrm{H}]^{+},\left[\mathrm{M}+\mathrm{Pb}+\mathrm{H}_{2} \mathrm{O}-\mathrm{H}\right]^{+}$and $\left[\mathrm{M}+\mathrm{Pb}+2 \mathrm{NO}_{3}+\mathrm{H}_{2} \mathrm{O}-\mathrm{H}\right]^{+}$, respectively. This was further confirmed by HR-ESI mass spectrometry (Figures S4-S7). All the assignments showed good agreement between the observed and calculated isotopic distributions.

IR Spectra. The IR spectrum of macrocycle 1 showed a characteristic $v(\mathrm{C}=\mathrm{O})$ absorption band for the $-\mathrm{COOH}$ group at $1,718 \mathrm{~cm}^{-1}$, which vanishes in the case of metal complex 2 . For the free peptide the $v_{\mathrm{as}}(\mathrm{COO})$ and $v_{\mathrm{s}}(\mathrm{COO})$ stretching vibrations of the carboxylate group appear at 1,545 and $1,444 \mathrm{~cm}^{-1}$ respectively, while for the lead complex 2, the first absorption region became broad and the second was obscured by the nitrate ion absorption, which displays a quite intense band at $1,384 \mathrm{~cm}^{-1}$ (Figures S8 and S9).

\subsection{Crystal Structures}

\subsubsection{Crystal Structure of CTP 1}

X-ray crystallographic studies showed a crystal structure of macrocycle 1 with a cis-trans-cis-trans (two transoid amide bonds between Gly-Ser, Pro-Glu and two cisoid amide bonds between Ser-Pro, and Glu-Gly) peptide bond, a sequence closely associated with biological activity. A summary of the crystal data and refinement results is listed in Table 1.

Table 1. Selected crystallographic data of $\mathbf{1}$ and 2.

\begin{tabular}{ccc}
\hline & $\mathbf{1}$ & $\mathbf{2}$ \\
\hline Empirical formula & $\mathrm{C}_{15} \mathrm{H}_{22} \mathrm{~N}_{4} \mathrm{O}_{7}$ & $\mathrm{C}_{15} \mathrm{H}_{25} \mathrm{~N}_{5} \mathrm{O}_{12} \mathrm{~Pb}$ \\
Formula weight & 370.37 & 674.59 \\
Temperature & $296(2) \mathrm{K}$ & $296(2) \mathrm{K}$ \\
Wavelength & 0.71073 & 0.71073 \\
Crystal system, space group & Monoclinic, $\mathrm{P} 2(1)$ & Monoclinic, $\mathrm{P} 2(1)$ \\
Unit cell dimensions & & \\
$\mathrm{a}(\AA)$ & $4.9855(7)$ & $5.0532(3)$ \\
$\mathrm{b}(\AA)$ & $17.257(3)$ & $17.7774(11)$ \\
$\mathrm{c}(\AA)$ & $9.7830(14)$ & $11.8317(5)$ \\
$\alpha\left(^{\circ}\right)$ & 90.00 & 90.00 \\
$\beta\left(^{\circ}\right)$ & $104.064(3)$ & $94.550(3)$ \\
$\gamma\left({ }^{\circ}\right)$ & 90.00 & 90.00 \\
Volume $\left(\AA^{3}\right)$ & $816.4(2)$ & $1059.52(10)$ \\
Z $^{\circ}$ Calculated density & $2,1.507$ & $2,2.115$ \\
Absorption coef. $\left(\mathrm{mm}{ }^{-1}\right)$ & 0.121 & 8.037 \\
$\mathrm{~F}(000)$ & 392 & 656 \\
Crystal size (mm) & $0.13 \times 0.08 \times 0.05$ & $0.44 \times 0.09 \times 0.05$ \\
$\theta$ range for data collection $\left({ }^{\circ}\right)$ & $2.15-28.10$ & $1.73-27.5$ \\
Limiting indices & $-5 \leq \mathrm{h} \leq 6,-22 \leq \mathrm{k} \leq 22,-12 \leq 1 \leq 12$ & $-6 \leq \mathrm{h} \leq 6,-23 \leq \mathrm{k} \leq 11,-14 \leq 1 \leq 15$ \\
Reflection collected/unique & $7693 / 3848[\mathrm{R}(\mathrm{int})=0.0395]$ & $6993 / 3657[\mathrm{R}(\mathrm{int})=0.0363]$ \\
Absorption correction & $\mathrm{Multi}-\mathrm{scan}$ & $\mathrm{Multi}-\mathrm{scan}$ \\
\hline
\end{tabular}


Table 1. Cont.

\begin{tabular}{ccc}
\hline & $\mathbf{1}$ & $\mathbf{2}$ \\
\hline Max. and min. transmission & 0.7456 and 0.6392 & 0.6990 and 0.1278 \\
Refinement method & Full-matrix least-squares on $\mathrm{F}^{2}$ & Full-matrix least-squares on $\mathrm{F}^{2}$ \\
Data/restraints/parameter & $3848 / 1 / 237$ & $3657 / 1 / 298$ \\
Goodness-of-fit on $\mathrm{F}^{2}$ & 1.063 & 0.949 \\
Final R indices [I $>$ 2sigma(I)] & $\mathrm{R}_{1}=0.0471, \mathrm{wR}_{2}=0.1071$ & $\mathrm{R}_{1}=0.0278, \mathrm{wR}_{2}=0.0618$ \\
R indices (all data) & $\mathrm{R}_{1}=0.0739, \mathrm{wR}_{2}=0.1292$ & $\mathrm{R}_{1}=0.0317, \mathrm{wR}_{2}=0.0636$ \\
Larg. diff. peak and hole $\left(\mathrm{e} . \AA^{-3}\right)$ & 0.214 and -0.222 e. $\AA^{-3}$ & 1.336 and -1.127 e. $\AA^{-3}$ \\
\hline
\end{tabular}

The backbone of the cyclic peptide adopts a two-fold symmetric conformation which is very common for cyclic tetrapeptides containing alternate 'cis' and 'trans' peptide units and the two side chains (glutamic and serine) are away from the ring. The glutamic residue assumes the gauche conformation to the main-chain amino group $\left(\chi^{1}=-54.6^{\circ}\right)$. In the prolyl residue, $\mathrm{C}^{\alpha}, \mathrm{C}^{\beta}, \mathrm{C}^{\delta}$ and $\mathrm{N}$ form an approximate plane with $\mathrm{C}^{\gamma}$ deviating from the plane by $0.56 \AA$ towards the side of the carbonyl group. The torsion angles that define the conformation of the molecule are listed in Table 2.

Table 2. Backbone and side-chain torsion angles $\left(^{\circ}\right)$ of $\mathbf{1}$.

\begin{tabular}{ccccc}
\hline Angle & Gly & L-Ser & L-Pro & L-Glu \\
\hline$\Phi$ & -98.2 & -134.5 & -84.3 & 55.1 \\
$\psi$ & -13.6 & 49.7 & 153.9 & 47.0 \\
$\omega$ & -176.07 & 2.91 & 177.26 & 13.45 \\
$\chi^{1}$ & & & 32.15 & -54.65 \\
$\chi^{2}$ & & -39.57 & 151.99 \\
$\chi^{3}$ & & 32.21 & \\
$\chi^{4}$ & & & \\
$\chi^{5}$ & & & -11.30 & \\
\hline
\end{tabular}

The conformation of the cyclic tetrapeptide $\mathbf{1}$ is illustrated in the Figure 1 (top, left). The overall shape of the backbone is a distorted boat with the cis amide bonds at the two ends which could facilitate ion binding.

Each discrete molecule of $c y c l o(G S P E) \mathbf{1}$ is strongly hydrogen bonded to a neighboring molecule through the amide $\mathrm{N}-\mathrm{H}$ of glutamic acid moiety to a carboxyl O-atom of proline $\left(d_{\mathrm{N}-\mathrm{H} \cdots \mathrm{O}} 2.066 \AA\right.$ and $\left.\theta_{\mathrm{N}-\mathrm{H} \cdots \mathrm{O}} 176.6^{\circ}\right)$ moiety and amide $\mathrm{N}-\mathrm{H}$ of serine to a carboxyl O-atom of a glycine moiety $\left(d_{\mathrm{N}-\mathrm{H} \cdots \mathrm{O}}\right.$ $1.997 \AA$ and $\theta_{\mathrm{N}-\mathrm{H} \cdots \mathrm{O}} 145.3^{\circ}$ ), to form a $1 \mathrm{D}$-chain along the a-axis. An oriented CTP nanotube (yellow) is thus assembled. The structure of this nanotube is expanded into a three-dimensional network $\left(5.4 \times 2.8 \AA^{2}\right)$, which is devoid of water molecules (Figure 1, top and right).

The carboxylic acid group of glutamic acid and the hydroxyl group of serine are flanked in opposite directions and are hydrogen bonded to a neighboring 1D-chain to form an overall 3D-network. Each cyclo(GSPE) 1 molecule is surrounded by four neighboring molecules and two molecules are hydrogen bonded (between amide $\mathrm{N}-\mathrm{H}$ of glycine moiety of neighboring molecule to carboxyl O-atom of glutamic acid moiety of the core molecule $\left(d_{\mathrm{N}-\mathrm{H} \cdots \mathrm{O}} 2.162 \AA\right.$ and $\left.\theta_{\mathrm{N}-\mathrm{H} \cdots \mathrm{O}} 154.1^{\circ}\right)$, and hydroxyl H-atom of serine from neighboring molecule to $\mathrm{O}$-atom of the amide group of the glutamic acid moiety 
$\left(d_{\mathrm{O}-\mathrm{H} \cdots \mathrm{O}} 1.999 \AA\right.$ and $\left.\theta_{\mathrm{O}-\mathrm{H} \cdots \mathrm{O}} 169.0^{\circ}\right)$ of the core molecule. The remaining two neighboring molecules are linked to the core molecule through $\mathrm{O} \cdots \mathrm{O}$ interactions between the amide $\mathrm{O}$-atom of the serine moiety to the O-atom of carboxylic acid group of glutamic acid $\left(d_{\mathrm{C}-\mathrm{O} \ldots \mathrm{O}} 2.605 \AA\right.$ and $\left.\theta_{\mathrm{C}-\mathrm{O} \ldots \mathrm{O}} 169.1^{\circ}\right)$ moiety (Figure 1, bottom).

Figure 1. Thermal ellipsoid plot of cyclo(Gly-L-Ser-L-Pro-L-Glu) 1. Color code: light gray, $\mathrm{C}$; blue, N; red, O; dark gray, $\mathrm{H}$.
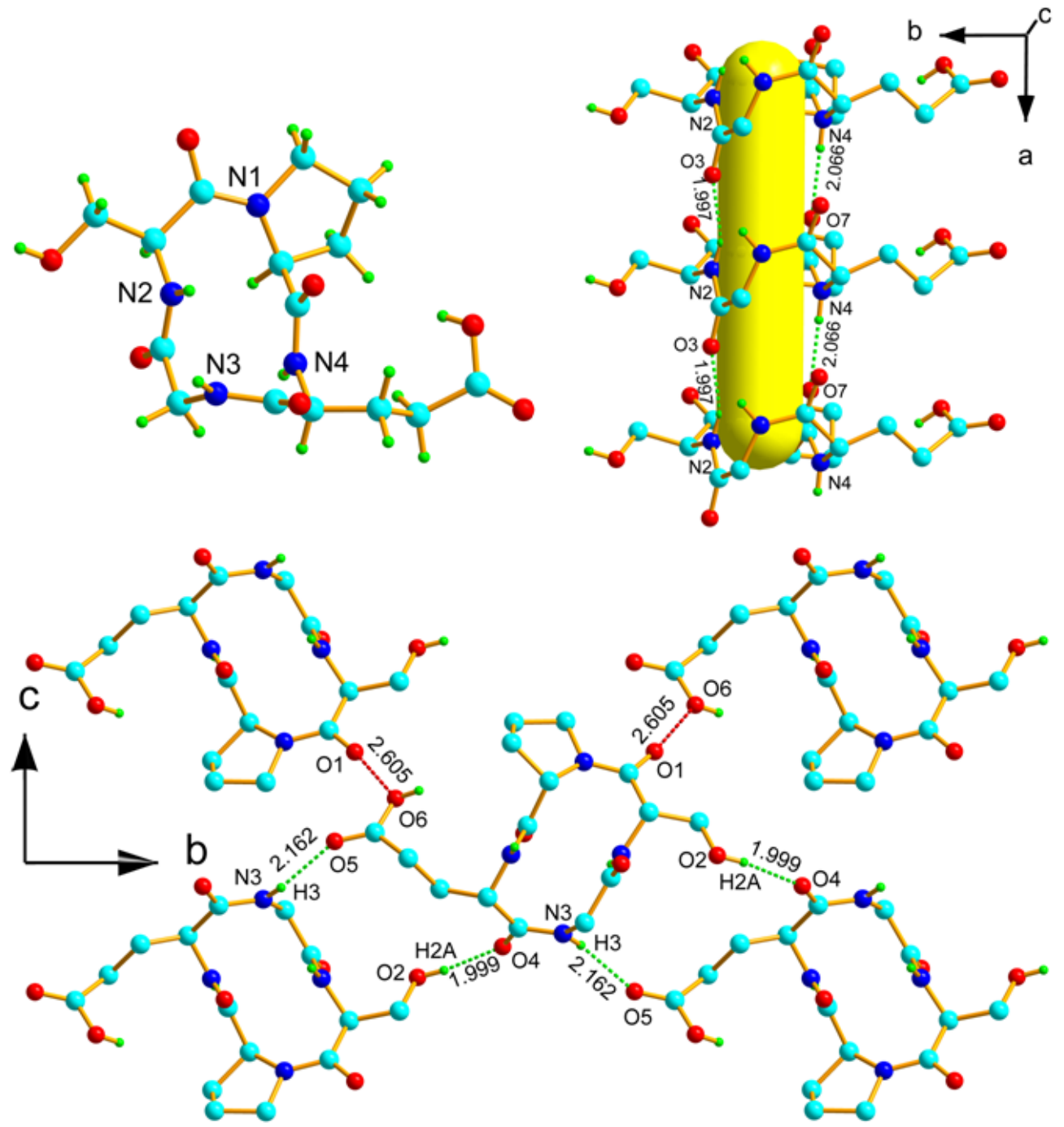

\subsubsection{Crystal Structure of Complex 2}

A single-crystal X-ray diffraction study reveals that complex 2 is a 3D-coordinated polymer, crystallized in the monoclinic system with $P$ 2(1) space group. Crystallographic data of $\mathbf{2}$ are listed in Table 1. As shown in Figure 2, the asymmetric unit of $\mathbf{2}$ is composed of one $\mathrm{Pb}$ (II) center, one deprotonated cyclo(GSPE) ligand, one nitrate molecule and two lattice water molecules. 
Figure 2. Crystal structure of 2. Perspective view showing binding mode of cyclo(Gly-LSer-L-Pro-L-Glu) 1 to $\mathrm{Pb}$ (II) ion. Only hydroxyl $\mathrm{O}-\mathrm{H}$ and amide $\mathrm{N}-\mathrm{H}$ group hydrogen atoms are shown.

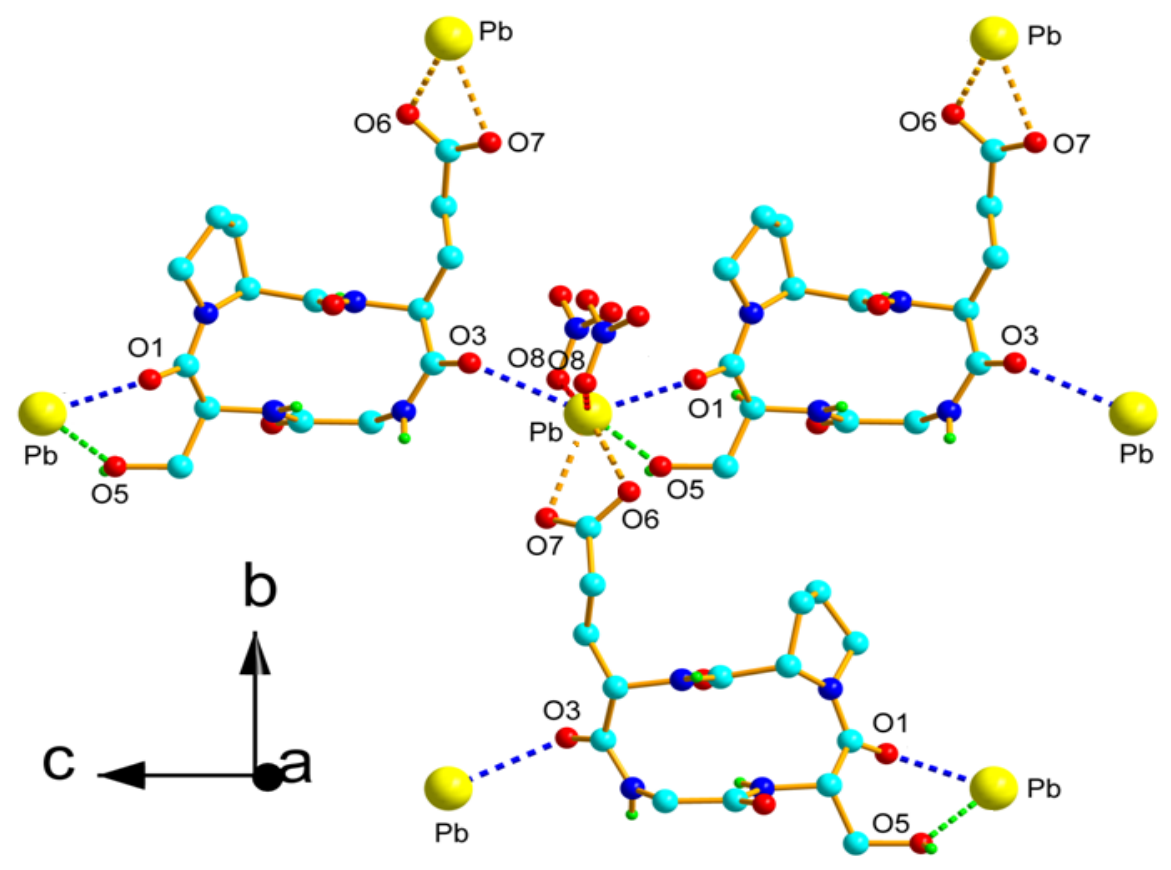

The $\mathrm{Pb}(\mathrm{II})$ center is in a seven coordination environment (Figure 2) with five oxygen atoms [O1(proline carbonyl), O3(glutamic carbonyl), O5(serine hydroxyl) O6 and O7(glutamic carboxylate)] of three distinct cyclo(GSPE) 1 ligands and two $\mu_{1,1^{-}}$oxygen atoms (O8) of nitrate molecules from two EO bridges (joining it to a neighboring $\mathrm{Pb}$ atom). The torsion angles that define the conformation of the complex 2 are listed in Table 3.

Table 3. Selected bond lengths $(\AA)$ and angles $\left(^{\circ}\right)$ of $\mathbf{2}$.

\begin{tabular}{cccc}
\hline $\mathrm{Pb}-\mathrm{O} 1$ & $2.489(4)$ & $\mathrm{Pb}-\mathrm{O} 3$ & $2.833(5)$ \\
$\mathrm{Pb}-\mathrm{O} 5$ & $2.475(5)$ & $\mathrm{Pb}-\mathrm{O} 6$ & $2.463(6)$ \\
$\mathrm{Pb}-\mathrm{O} 7$ & $2.644(6)$ & $\mathrm{Pb}-\mathrm{O} 8$ & $2.571(5)$ \\
$\mathrm{Pb}-\mathrm{O} 8$ & $2.755(5)$ & & \\
$\mathrm{O} 6-\mathrm{Pb}-\mathrm{O} 5$ & $73.42(19)$ & $\mathrm{O} 6-\mathrm{Pb}-\mathrm{O} 1$ & $80.12(17)$ \\
$\mathrm{O} 5-\mathrm{Pb}-\mathrm{O} 1$ & $69.53(16)$ & $\mathrm{O} 6-\mathrm{Pb}-\mathrm{O} 8$ & $71.78(19)$ \\
$\mathrm{O} 5-\mathrm{Pb}-\mathrm{O} 8$ & $135.80(18)$ & $\mathrm{O} 1-\mathrm{Pb}-\mathrm{O} 8$ & $78.36(16)$ \\
$\mathrm{O} 6-\mathrm{Pb}-\mathrm{O} 7$ & $50.55(17)$ & $\mathrm{O} 5-\mathrm{Pb}-\mathrm{O} 7$ & $78.39(19)$ \\
$\mathrm{O} 1-\mathrm{Pb}-\mathrm{O} 7$ & $127.25(17)$ & $\mathrm{O} 8-\mathrm{Pb}-\mathrm{O} 7$ & $99.17(19)$ \\
$\mathrm{O} 6-\mathrm{Pb}-\mathrm{O} 8$ & $145.03(18)$ & $\mathrm{O} 5-\mathrm{Pb}-\mathrm{O} 8$ & $75.99(18)$ \\
$\mathrm{O} 1-\mathrm{Pb}-\mathrm{O} 8$ & $104.61(16)$ & $\mathrm{O} 8-\mathrm{Pb}-\mathrm{O} 8$ & $143.1(3)$ \\
$\mathrm{O} 7-\mathrm{Pb}-\mathrm{O} 8$ & $106.82(18)$ & $\mathrm{O} 6-\mathrm{Pb}-\mathrm{O} 3$ & $129.40(16)$ \\
$\mathrm{O} 5-\mathrm{Pb}-\mathrm{O} 3$ & $143.21(16)$ & $\mathrm{O} 1-\mathrm{Pb}-\mathrm{O} 3$ & $134.98(17)$ \\
$\mathrm{O} 8-\mathrm{Pb}-\mathrm{O} 3$ & $80.86(17)$ & $\mathrm{O} 7-\mathrm{Pb}-\mathrm{O} 3$ & $95.17(17)$ \\
$\mathrm{O} 8-\mathrm{Pb}-\mathrm{O} 3$ & $71.33(15)$ & & \\
\hline
\end{tabular}

The geometry around the $\mathrm{Pb}$ center appears holodirected [39]. The bidentate carboxylate oxygen atoms (O6 and $\mathrm{O} 7$ ) provided the asymmetric chelation ( $\mathrm{Pb}-\mathrm{O} 2.463(6)$ and 2.643 (6) $\AA$ ). The $\mathrm{Pb}-\mathrm{O}$ 
bond distances (Table 3) are in the range of 2.463(6)-2.833(5) $\AA$ and the O-Pb-O bond angles vary from 50.55(17)-145.03(18) $)^{\circ}$ and are comparable to those reported earlier for lead-oxygen donor complexes [24,40-42]. 1D linear chain around the $\mathrm{Pb}$ center is formed via carbonyl and hydroxyl oxygen atoms of two distinct cyclo(GSPE) ligands along [001] direction (Figure 3).

Figure 3. View of the 1D linear chain of 2 along [001] direction. Color code: green, $\mathrm{Pb}$; gray, C; blue, N; red, O.

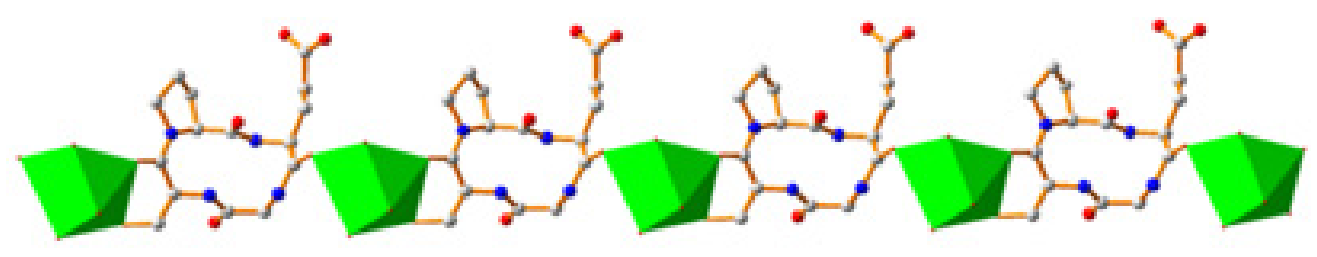

Three molecules of cyclo(GSPE) 1 binds with three $\mathrm{Pb}$ (II) ions to form one cyclic ring and the same unit repeats along b-axis to form a 2D layer structure (Figure 4a,b). When viewed along the [100] direction, these sheets are further cross-linked by $\mathrm{NO}_{3}{ }^{-}$molecules giving rise to a three-dimensional structure. The size and the shape of the CTP nanotube remains unchanged (Figure 5).

Figure 4. (a) Perspective view of 2D-network along a-axis. Color code: yellow, Pb; cyan, $\mathrm{C}$; blue, N; red, O. (b) 2D sheet of 2 in the bc plane. Color code: green, $\mathrm{Pb}$; gray, $\mathrm{C}$; blue, $\mathrm{N} ;$ red, O.

(a)

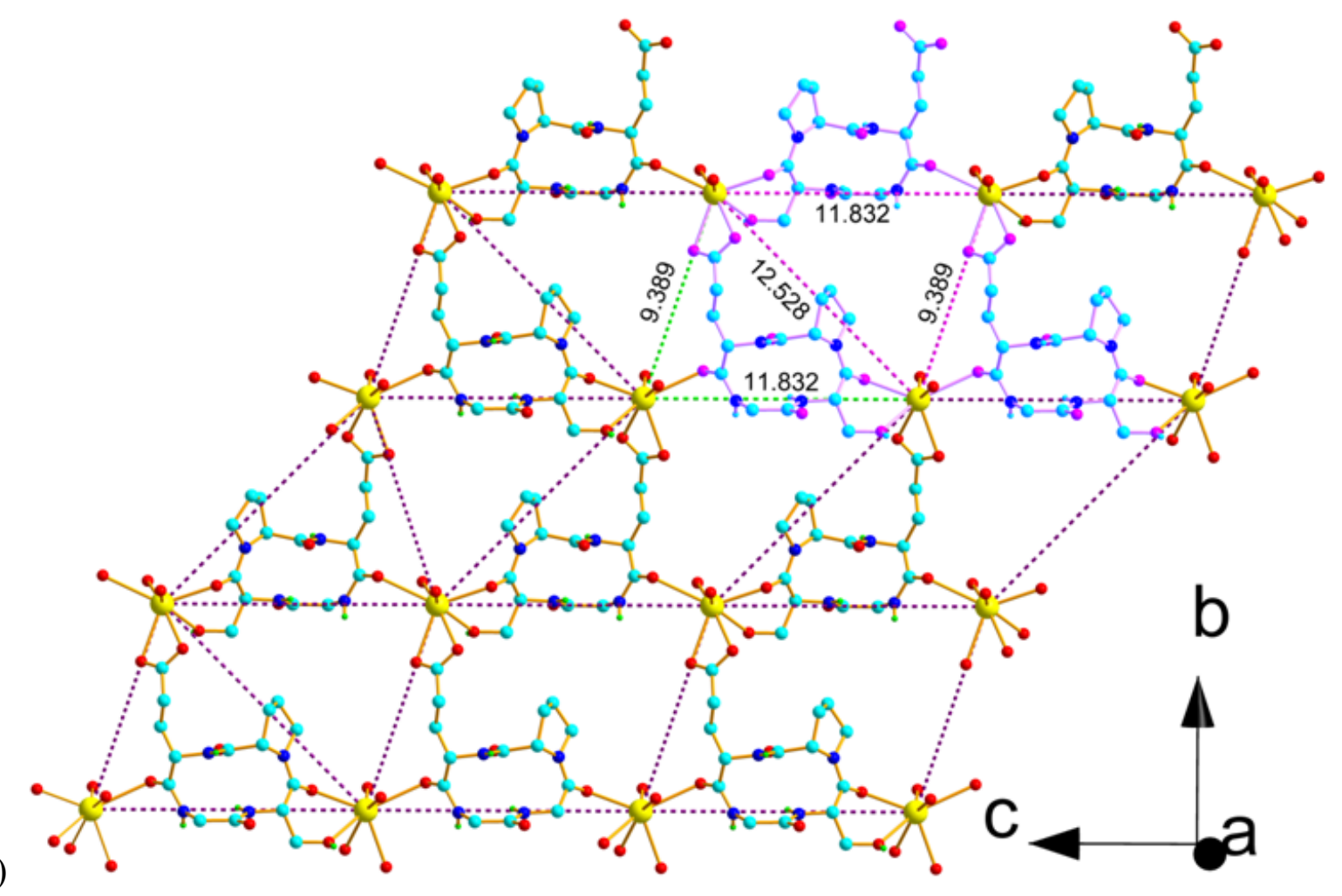


Figure 4. Cont.

(b)

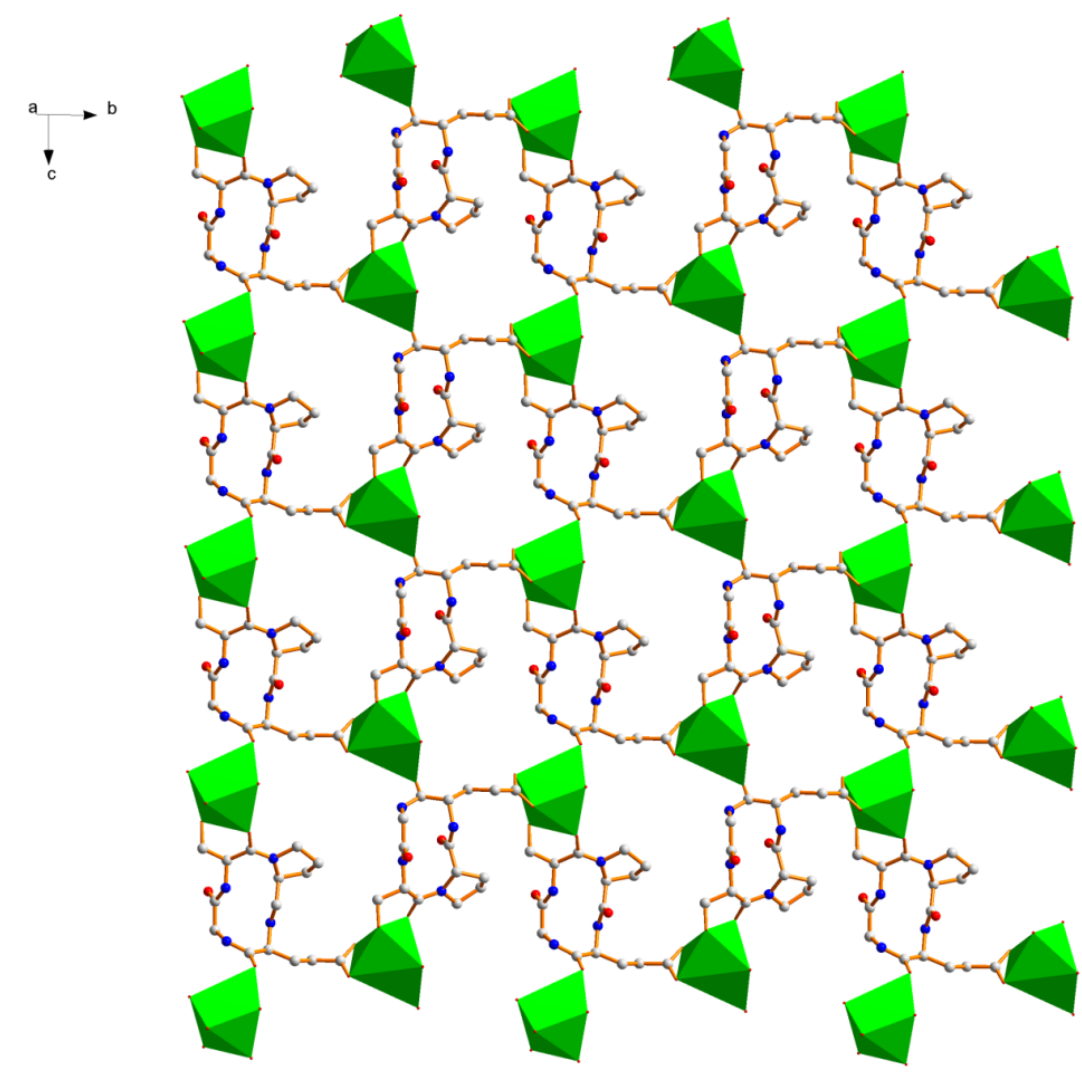

Figure 5. Polyhedral view in three-dimensional structure of 2. Color code: green, $\mathrm{Pb}$; gray, C; blue, N; red, O.

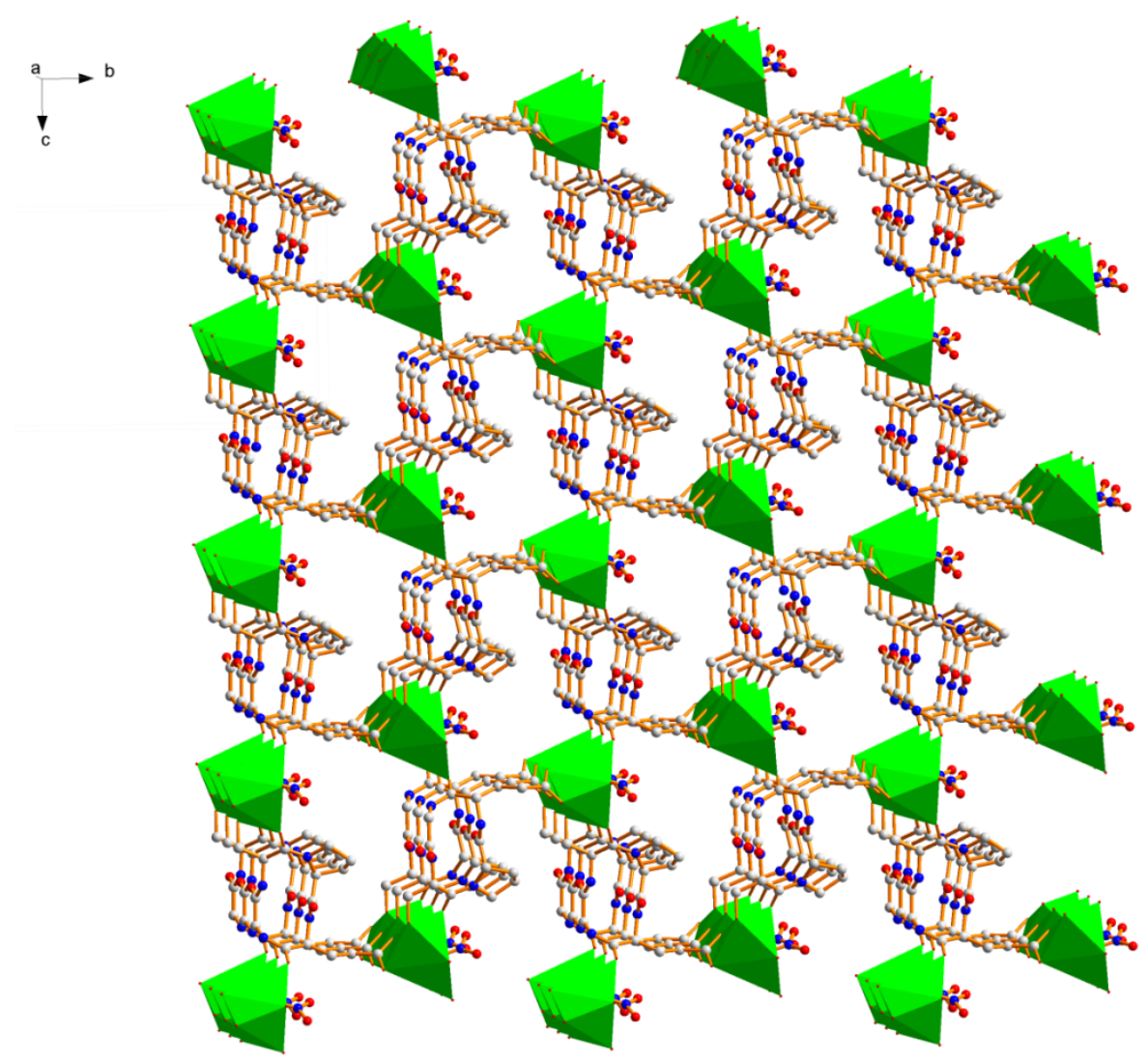


Two adjacent $\mathrm{Pb}(\mathrm{II})$ ions in $\mathbf{2}$ are bridged by one oxygen atom from $\mu_{1,1}$-bridging $\mathrm{NO}_{3}{ }^{-}$molecule (Figure 6) to build a dinuclear unit with a $\mathrm{Pb} \cdots \mathrm{Pb}$ distance of 5.053(0) $\AA$. Of three coordinated nitrates to $\mathrm{Pb}(\mathrm{II})$, one nitrate faces the cavity of the cage (Figure 6 , left) and the remaining two nitrate anion lie in neighboring cavities. The coordinated nitrate facing the cavity of the cage interact with one (out of two) water molecule inside cage $\left(d_{\mathrm{O} 11-\mathrm{H} 11 \ldots \mathrm{O} 10} 2.207 \AA, \theta_{\mathrm{O} 11-\mathrm{H} 11 \ldots \mathrm{O} 10} 155.7(53)^{\circ}\right)$.

Figure 6. Perspective view of hydrogen bonded (between amide $\mathrm{N}-\mathrm{H}$ and carbonyl $\mathrm{O}$-atom) cage (left) of two layer and each cyclic layer formed by three cyclo(Gly-L-Ser-LPro-L-Glu) 1 molecule coordinated to three $\mathrm{Pb}(\mathrm{II})$ ions. Between two layers, nitrate anions are weakly coordinated to two $\mathrm{Pb}$ (II) ions of each layer (right). Out of three nitrate anion, one nitrate anion lying inside the cage is further coordinated to a water molecule and the remaining two nitrate anions lying inside two neighboring cages. For clarity, each layer is differentiated from neighboring layer by different color.
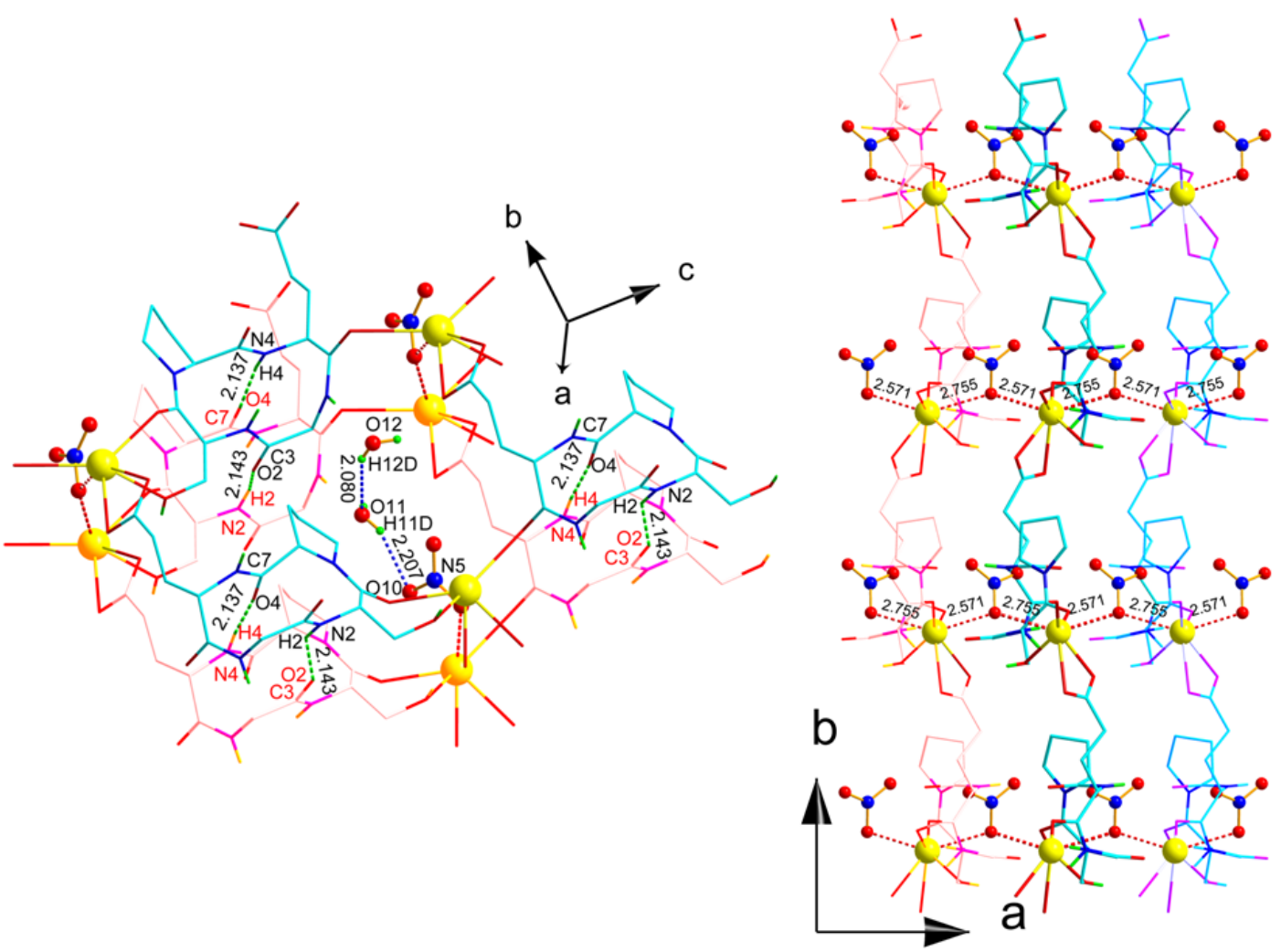

\subsection{Discussion}

There is no report on the solid state structure of a natural (12-membered) cyclic tetrapeptide with a metal ion. The molecular structure of the $c y c l o(G S P E)-P b$ complex 2 is unique as all the complexes reported to date are with higher cyclic peptides or $\beta$-cyclic tetrapeptides and are sandwich complexes [43-45]. Structure 2 showed that conformation of 1 remains cis-trans-cis-trans and only the side chains and ring carbonyls are pointing towards the $\mathrm{Pb}$ metal for binding and, hence, represent an example of a metal complex bound with both a cyclic skeleton and functional groups in side chains. Unlike linear peptides, the retention of conformation of $\mathbf{1}$ is attributed to the highly constrained nature of CTPs. The rigidity of cyclopeptide backbones ensures the formation of nanotubes [46]. The inability 
to adjust their conformation makes CTP-metal complexes rare. However, once it formed, the resulting CTP-metal complexes 2 will preserve the nanotubes.

\section{Experimental}

\subsection{Materials and Physical Measurements}

All reagents were commercially available (Aldrich, Saint Louis, MO, USA or Merck, Darmstadt, Germany) and used as supplied. Solvents were dried by standard procedures. The NMR spectra were recorded on a Bruker DRX $400\left({ }^{1} \mathrm{H}\right.$ at $400.13 \mathrm{MHz},{ }^{13} \mathrm{C}$ at $100.03 \mathrm{MHz}$ ) spectrometer (Bruker Daltonik, Bremen, Germany). MALDI TOF was performed on a Bruker Autoflex MALDI-TOF mass spectrometer (Bruker Daltonik, Bremen, Germany). High-resolution electrospray ionization mass spectrometry (ESI-MS) was performed on a Shimadzu-LCMS-IT-TOF mass spectrometer (Shimadzu, Kyoto, Japan). Elemental analysis for $\mathrm{C}, \mathrm{H}, \mathrm{N}$ was performed on VarioEL-III elementar analyzer (Elementar, Hanau, Germany). Infrared spectra were recorded on a PerkinElmer Spectrum one FT-IR spectrometer (PerkinElmer, Shelton, CT, USA) using KBr pellets $\left(4,000-400 \mathrm{~cm}^{-1}\right)$.

\subsection{Sythesis}

Cyclo(Gly-L-Ser-L-Pro-L-Glu) (1). Linear peptide Boc-GS(OBn)PE(OBn) $)_{2}$ was synthesized by using standard solution-phase peptide coupling protocols starting from Fmoc-L-proline. Subsequently, regioselective enzymatic hydrolysis of the $\alpha$-benzyl ester on glutamate was achieved [47]. The linear precursor was then activated with pentafluorophenol and cyclized with pyridine to form dibenzyl protected CTP [48]. Deprotection of the benzyl group finished the synthesis of $\mathbf{1}$. The overall yield was 19\%. IR ( $\left.\mathrm{KBr}, \mathrm{cm}^{-1}\right): 3459 v(\mathrm{NH}), 3236 v\left(\mathrm{OH}\right.$ vs $\left.-\mathrm{CH}_{2} \mathrm{OH}\right), 3066 v(\mathrm{CH}), 29902961 v\left(\mathrm{CH}_{2}\right), 1718$ $v(\mathrm{C}=\mathrm{O}$ vs $-\mathrm{COOH}), 166316461615 v(\mathrm{C}=\mathrm{O}$ vs amide $), 1545 v_{\mathrm{as}}(\mathrm{COO}), 1444 v_{\mathrm{s}}(\mathrm{COO}) .{ }^{1} \mathrm{H}-\mathrm{NMR}$ : $\left(\mathrm{D}_{2} \mathrm{O}\right) \delta 1.60-1.89(\mathrm{~m}, 3 \mathrm{H}), 1.93-2.17(\mathrm{~m}, 3 \mathrm{H}), 2.20-2.38(\mathrm{~m}, 2 \mathrm{H}), 3.36-3.54(\mathrm{~m}, 2 \mathrm{H}), 3.57-3.65(\mathrm{~m}$, $1 \mathrm{H}), 3.77-3.82(\mathrm{~m}, 1 \mathrm{H}), 3.86-3.97(\mathrm{~m}, 2 \mathrm{H}), 4.08-4.10(\mathrm{~d}, 1 \mathrm{H}, J=8 \mathrm{~Hz}), 4.35-4.37$ (d, $1 \mathrm{H}, J=8 \mathrm{~Hz})$, 4.80-4.82 (m, 1H). MALDI-TOF: $m / z 371.35[\mathrm{M}+\mathrm{H}]^{+}$, ESI-MS: [M-H] ${ }^{-}$calculated $\mathrm{m} / z$ 369.1488, obtained $\mathrm{m} / \mathrm{z} 369.1426$.

$\left\{\left[\right.\right.$ cyclo $\left.(G l y-L-S e r-L-P r o-L-G l u) P b\left(\mathrm{NO}_{3}\right)\right] \cdot 2 \mathrm{H}_{2} \mathrm{O}_{n}(2) . \mathrm{Pb}\left(\mathrm{NO}_{3}\right)_{2}(4.5 \mathrm{mg}, 13.5 \mu \mathrm{mol})$ was dissolved in water $(1 \mathrm{~mL})$. cyclo(GSPE) $1(5.0 \mathrm{mg}, 13.5 \mu \mathrm{mol})$ was dissolved in water $(1 \mathrm{~mL})$ and added to the metal solution. The $\mathrm{pH}$ of solution was adjuted to 5 with diluted $\mathrm{HNO}_{3}$ solution. The reaction mixture was stirred at RT for 10 minutes and then at $70{ }^{\circ} \mathrm{C}$ for 4 days. Crystals suitable for X-ray diffraction were obtained from saturated solution by slow cooling. Anal. Calc. for $\mathrm{C}_{15} \mathrm{H}_{25} \mathrm{~N}_{5} \mathrm{O}_{12} \mathrm{~Pb}$ (674.6): $\mathrm{C}$ 26.70, H 3.73, N 10.38, O 28.46. Found: C 26.23, H 2.94, N 10.64, O 28.17. IR (KBr, cm $\left.{ }^{-1}\right): 3433, v(\mathrm{NH})$; 1645, $v\left(\mathrm{C}=\mathrm{O}\right.$ vs amide); 1384, v( $\left(\mathrm{NO}_{3}\right) .{ }^{1} \mathrm{H}-\mathrm{NMR}:\left(\mathrm{D}_{2} \mathrm{O}\right)$ 1.86-1.99 (m, 3H); 2.04-2.31 (m, 3H); 2.35-2.53 (m, 2H); 3.45-3.55 (m, 1H); $3.59(\mathrm{~s}, 1 \mathrm{H}) ; 3.65-3.71(\mathrm{~m}, 1 \mathrm{H}) ; 3.73-3.81(\mathrm{~m}, 1 \mathrm{H}) ; 3.82(\mathrm{~s}$, $1 \mathrm{H}) ; 3.87-4.00(\mathrm{~m}, 1 \mathrm{H}) ; 4.19-4.26(\mathrm{~m}, 1 \mathrm{H}) ; 4.38-4.45(\mathrm{~m}, 1 \mathrm{H}) ; 4.76(\mathrm{t}, 1 \mathrm{H}, J=5.88 \mathrm{~Hz})$. MALDI-TOF: $m / z 577.69[\mathrm{M}+\mathrm{Pb}-\mathrm{H}]^{+}, 595.71\left[\mathrm{M}+\mathrm{Pb}+\mathrm{H}_{2} \mathrm{O}-\mathrm{H}\right]^{+}$and $719.69\left[\mathrm{M}+\mathrm{Pb}+2 \mathrm{NO}_{3}+\mathrm{H}_{2} \mathrm{O}-\mathrm{H}\right]^{+}$. ESI-MS: $[\mathrm{M}+\mathrm{Pb}-\mathrm{H}]^{+}$calculated $\mathrm{m} / \mathrm{z}$ 577.1177, obtained $\mathrm{m} / \mathrm{z}$ 577.1183; $\left[\mathrm{M}+\mathrm{Pb}+\mathrm{NO}_{3}-\mathrm{H}\right]^{+}$calculated $\mathrm{m} / \mathrm{z}$ 
639.1055, obtained $\mathrm{m} / \mathrm{z}$ 639.1049; $\left[\mathrm{M}+\mathrm{Pb}+2 \mathrm{NO}_{3}-\mathrm{H}\right]^{+}$calculated $\mathrm{m} / \mathrm{z}$ 701.0933, obtained $\mathrm{m} / \mathrm{z}$ 701.0973; $\left[\mathrm{M}+\mathrm{Pb}+2 \mathrm{NO}_{3}+2 \mathrm{H}_{2} \mathrm{O}+\mathrm{H}\right]^{+}$calculated $m / z$ 739.1301, obtained $\mathrm{m} / \mathrm{z}$ 739.2925.

\subsection{X-ray Crystallography}

Colorless prism-like crystals of $\mathbf{1}$ and rod-like crystals of $\mathbf{2}$ were obtained by slow solvent evaporation at room temperature, respectively. Crystals suitable for X-ray diffraction analysis were selected with size of $0.13 \times 0.08 \times 0.05 \mathrm{~mm}$ for 1 and $0.44 \times 0.09 \times 0.05 \mathrm{~mm}$ for 2 . Crystals were mounted on a glass fiber and used for data collection. For both compounds $\mathbf{1}$ and $\mathbf{2}$ diffraction data were preliminarily collected with a Bruker APEX-II CCD diffractometer using graphite monochromated MoKa radiation $(\lambda=0.71073 \AA)$. Absorption corrections for the area detector were performed with the program SADABS. Structures were solved by direct methods and were refined against the least-squares methods on $F 2$ with the SHELXL-97 package, incorporated in SHELXTL/PC V5. Anisotropic thermal factors were used only for all non-hydrogen atoms.

CCDC 831318 and 831319 contains the supplementary crystallographic data for this paper. These data can be obtained free of charge via www.ccdc.cam.ac.uk/conts/retrieving.html (or from the CCDC, 12 Union Road, Cambridge CB2 1EZ, UK; fax: +44 1223 336033; e-mail: deposit@ccdc.cam.ac.uk).

\section{Conclusions}

We have developed the synthesis of a CTP cyclo(GSPE) 1. The synthetic building blocks were coupled through hydroxyl, carboxylate and two amide bonds to lead ion and thus created watersoluble, coordination polymers (tris-CTPs) with well-defined three-dimensional structures. This is the first report of a naturally occurring CTP as the host for metal complexation. The CTP retains its conformation through the binding process with metals. The unique crystal structure of this rigid molecule suggests the formation of a designated complex with nanotube properties.

\section{Supplementary Materials}

Supplementary materials can be accessed at: http://www.mdpi.com/1420-3049/18/5/4972/s1.

\section{Acknowledgments}

The present work is supported by a Grant from the National Science Council of Taiwan.

\section{Conflict of Interest}

The authors declare no conflict of interest.

\section{References}

1. Horcajada, P.; Gref, R.; Baati, T.; Allan, P.K.; Maurin, G.; Couvreur, P.; Ferey, G.; Morris, R.E.; Serre, C. Metal organic frameworks in biomedicine. Chem. Rev. 2012, 112, 1232-1268.

2. Keskin, S.; Kızılel, S. Biomedical applications of metal organic frameworks. Ind. Eng. Chem. Res. 2011, 50, 1799-1812. 
3. Ulijn, R.V.; Smith, A.M. Designing peptide based nanomaterials. Chem. Soc. Rev. 2008, 37, 664-675.

4. Scanlon, S.; Aggeli, A. Self-assembling peptide nanotubes. Nanotoday 2008, 3, 22-30.

5. Valery, C.; Franck Artzner, F.; Paternostre, M. Peptide nanotubes: Molecular organisations, self-assembly mechanisms and applications. Soft Matter 2011, 7, 9583-9594.

6. Lee, H.-Y.; Kampf, J.W.; Park, K.S.; Marsh, E.N.G. Covalent metal-peptide framework compounds that extend in one and two dimensions. Cryst. Growth Des. 2008, 8, 296-303.

7. Mantion, A.; Massuger, L.; Rabu, P.; Palivan, C.; McCusker, L.B.; Taubert, A. Design, Synthesis, Biological evaluation, and structural characterization of potent histone deacetylase inhibitors based on cyclic $\alpha / \beta$ - tetrapeptide architectures. J. Am. Chem. Soc. 2008, 130, 2517-2526.

8. Ghadiri, M.R.; Granja, J.R.; Milligan, R.A.; McRee D.E.; Khazanovich, N. Self-assembling organic nanotubes based on a cyclic peptide architecture. Nature 1993, 366, 324-327.

9. Ghadiri, M.R.; Granja J.R.; Buehler, L.K. Artificial transmembrane ion channels from self-assembling peptide nanotubes. Nature 1994, 369, 301-304.

10. Yang, L.; Tan, R.-X.; Wang, Q.; Huang, W.-Y.; Yin, Y.-X. Antifungal cyclopeptides from halobacillus litoralis YS3106 of marine origin. Tetrahedron Lett. 2002, 43, 6545-6548.

11. Mitova, M.; Tommonaro, G.; De Rosa, S. A novel cyclopeptide from a bacterium associated with the marine sponge Ircinia muscarum. Z. Naturforsch 2003, 58c, 740-745.

12. Shin, J.; Seo, Y.; Lee, H.-S.; Rho, J.-R.; Mo, S.J. A new cyclic peptide from a marine-derived bacterium of the Genus Nocardiopsis. J. Nat. Proc. 2003, 66, 883-884.

13. Rungprom, W.; Siwu, E.R.O.; Lambert, L.K.; Dechsakulwatana, C.; Barden, M.C.; Kokpol, U.; Blanchfield, J.T.; Kita, M.; Garson, M.J. Cyclic tetrapeptides from marine bacteria associated with the seaweed diginea sp. and the sponge halisarca ectofibrosa. Tetrahedron 2008, 64, 3147-3152.

14. Gu, W.; Cueto, M.; Jensen, P.R.; Fenical, W.; Silverman, R.B. Microsporins A and B: New histone deacetylase inhibitors from the marine-derived fungus microsporum cf. gypseum and the solid-phase synthesis of microsporin A. Tetrahedron 2007, 63, 6535-6541.

15. Thomas, D.; Walter, G.; Hans, B. Natural cyclopeptaibiotics and related cyclic tetrapeptides: Structural diversity and future prospects. Chem. Biodiv. 2008, 5, 693-706.

16. Nakao, Y.; Yoshida, S.; Matsunaga, S.; Shindoh, N.; Terada, Y.; Nagai, K.; Yamashita, J.K.; Ganesan, A.; Van Soes, R.W.M.; Fusetani, N. Azumamides A-E: Histone deacetylase inhibitory cyclic tetrapeptides from the marine sponge Mycale izuensis. Angew. Chem. Int. Ed. 2006, 45, 7553-7557.

17. Montero, A.; Beierle, J.M.; Olsen, C.A.; Ghadiri, M.R. Design, Synthesis, Biological evaluation, and structural characterization of potent histone deacetylase inhibitors based on cyclic alpha/beta-tetrapeptide architectures. J. Am. Chem. Soc. 2009, 131, 3033-3041.

18. Kawagishi, H.; Somoto, A.; Kuranari J.; Kimura, A.; Chiba, S. A novel cyclotetrapeptide produced by Lactobacillus helveticus as a tyrosinase inhibitor. Tetrahedron Lett. 1993, 34, 3439-3440.

19. Lacouture, F.; Francois, M.; Didierjean, C.; Rivera, J.P.; Rocca, E.; Steinmetz, J. Anhydrous lead(II) heptanoate. Acta Crystallogra C 2001, 57, 530-531.

20. Ferrari, R.; Bernes, S.; Barbarin, C.R.D.; Mendoza-Diaz, G.; Gasque, L. Interaction between glyglu and $\mathrm{Ca}^{2+}, \mathrm{Pb}^{2+}, \mathrm{Cd}^{2+}$ and $\mathrm{Zn}^{2+}$ in solid state and aqueous solution.: Crystal structures of

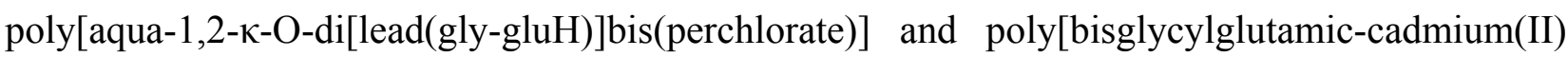
tetrahydrate]. Inorg. Chim. Acta 2002, 339, 193-201. 
21. Lei, Z.-H.; Li, X.; Dong, L.-N. Synthesis, Structure, and luminescence of a novel lead(II) coordination polymer with 1,2- phenylenediacetic acid. Inorg. Chem. Commun. 2010, 13, 1383-1386.

22. Zhang, X.; Cheng, J.-K.; Yin, P.-X.; Yao, Y.-G. Synthesis and characterization of a novel coordination polymer with isolated tetranuclear lead(II) clusters as building subunits. J. Mol. Struc. 2011, 990, 1-5.

23. Chen, S.-C.; Zhang, Z.-H.; Zhou, Y.-S.; Zhou, W.-Y.; Li, Y.-Z.; He. M.-Y.; Chen, Q.; Du, M. Alkali-metal-templated assemblies of new 3D lead(II) tetrachloroterephthalate coordination frameworks. Cryst. Growth Des. 2011, 11, 4190-4197.

24. Peedikakkal, A.M.P.; Vittal, J.J. Structural transformations of $\mathrm{Pb}(\mathrm{II})$-trans-1,2-bis(4'pyridyl)ethane coordination polymers in solution. Cryst. Growth Des. 2011, 11, 4697-4703.

25. Zhao, Y.-H.; Xu, H.-B.; Shao, K.-Z.; Xing, Y.; Su, Z.-M.; Ma, J.-F. Syntheses, Characterization, and luminescent properties of three 3D lead-organic frameworks with 1D Channels. Cryst. Growth Des. 2007, 7, 513-520.

26. Farrer, B.T.; Pecoraro, V.L. Heavy-metal complexation by de novo peptide design. Curr. Opin. Drug Discov. Dev. 2002, 5, 937-943.

27. Claudio, E.S.; Godwin, H.A.; Magyar, J.S. Fundamental coordination chemistry, environmental chemistry, and biochemistry of lead(II). Progr. Inorg. Chem. 2003, 51, 1-144.

28. Saxena, G.; Flora, S.J.S. Lead-induced oxidative stress and hematological alterations and their response to combined administration of calcium disodium EDTA with a thiol chelator in rats. J. Biochem. Mol. Toxicol. 2004, 18, 221-233.

29. Magyar, J.S.; Weng, T.C.; Stern, C.M.; Dye, D.F.; Rous, B.W.; Payne, J.C.; Bridgewater, B.M.; Mijovilovich, A.; Parkin, G.; Zaleski, J.M.; et al. Reexamination of lead(II) coordination preferences in sulfur-rich sites: implications for a critical mechanism of lead poisoning. J. Am. Chem. Soc. 2005, 127, 9495-9505.

30. Gracia, R.C.; Snodgrass, W.R. Lead toxicity and chelation therapy. Am. J. Health Syst. Pharm. 2007, 64, 45-53.

31. Chakraborty, S.; Kravitz, J.Y.; Thulstrup, P.W.; Hemmingsen, L.; DeGrado, W.F.; Pecoraro, V.L. Design of a three-helix bundle capable of binding heavy metals in a triscysteine environment. Angew. Chem. Int. Ed. 2011, 50, 2049-2053.

32. Mitova, M.; Popov, S.; De Rosa, S. Cyclic peptides from a Ruegeria strain of bacteria associated with the sponge Suberites domuncula. J. Nat. Prod. 2004, 67, 1178-1181.

33. Lim, H.A.; Kang, C.; Chia, C.S.B. Solid-phase synthesis and NMR structural studies of the marine antibacterial cyclic tetrapeptide: cyclo[GSPE]. Int. J. Pept. Res. Ther. 2010, 16, 145-152.

34. Davidovich, R.L.; Stavila, V.; Marinin, D.V.; Voit, E.I.; Whitmire, K.H. Stereochemistry of lead(II) complexes with oxygen donor ligands. Coord. Chem. Rev. 2009, 253, 1316-1352.

35. Pan, Q.-H.; Chen, Q.; Chang, Z.; Nhao, Y.-C.; Wang, Y.-C.; He, T.-L. A 3D lead(II) coordination polymer containing helical chains with rare ecl topology. Chin. J. Inorg. Chem. 2010, 26, 2299-2302.

36. Kong, Z.G.; Ma, X.Y.; Xu, Z.L.; Wang, X.Y. Synthesis and crystal structure of a new lead coordination polymer: $[\mathrm{Pb}(\mathrm{L})(1,4-\mathrm{ndc})]$. Chin. J. Struc. Chem. 2010, 29, 1749-1752. 
37. Zhang, Y.Y.; Liu, S.X.; Du, K.K.; Xue, M.X. A 3D-diamond-like coordination network of lead(II) complex: Synthesis, Structure and luminescent property. Inorg. Chem. Commun. 2010, 13, 641-644.

38. Shaabani, B.; Mirtamizdoust, B.; Viterbo, D.; Croce, G.; Hammud, H.; Hojati-Lalemi, P.; Khandar, A.; Anorg. Z. Sonochemical synthesis of a novel nanoscale lead(II) coordination polymer: Synthesis, Crystal structure, Thermal properties, and DFT calculations of $\left[\mathrm{Pb}(\mathrm{dmp})\left(\mu-\mathrm{N}_{3}\right)\left(\mu-\mathrm{NO}_{3}\right)\right]_{n}$ with the novel $\mathrm{Pb} 2\left(\mu-\mathrm{N}_{3}\right) 2\left(\mu-\mathrm{NO}_{3}\right)_{2}$ unit. Allg. Chem. 2011, 637, 713-719.

39. Shimoni-Livny, L.; Glusker, J.P.; Bock, C.W. Lone pair functionality in divalent lead compounds. Inorg. Chem. 1998, 37, 1853-1867.

40. Saunders, C.D.L.; Longobardi, L.E.; Burford, N.; Lumsden, M.D.; Zwanziger, U.W.; Chena, B.; McDonald, R. Comprehensive chemical characterization of complexes involving lead-amino acid interactions. Inorg. Chem. 2011, 50, 2799-2810.

41. Sun, J.-Y.; Wang, W.; Wang, L.; Zhang, D.-J.; Chen, Y.-L.; Ji, X.-D.; Fan, Y.; Song, T.-Y. Novel lead-organic framework based on 2,2'-bipyridine-3,3'-dicarboxylate ligand: Synthesis, structure and luminescence. J. Mol. Stru. 2011, 990, 204-208.

42. Chen, Z.; Yan, J.; Xing, H.; Zhang, Z.; Liang, F. Two lead(II) 2,4-dioxo-1,2,3,4tetrahydropyrimidine-5-carboxylate complexes exhibiting different topologies and fluorescent properties. J. Solid State Chem. 2011, 184, 1063-1069.

43. Kartha, G.; Varughese, K.I.; Aimoto, S. Conformation of cyclo(-L-Pro-Gly-) 3 and its $\mathrm{Ca}^{2+}$ and $\mathrm{Mg}^{2+}$ complexes. Proc. Natl. Acad. Sci. USA 1982, 79, 4519-4522.

44. Doi, M.; Asano, A.; Ishida, T.; Katsuya, Y.; Mezaki, Y.; Sasaki, M.; Terashima, A.; Taniguchi, T.; Hasegawa, H.; Shionod, M. Caged and clustered structures of endothelin inhibitor BQ123, cyclo(D-Trp-D-Asp-Pro-D-Val- Leu-). $\mathrm{Na}^{+}$, forming five and six coordination bonds between sodium ions and peptides. Acta Cryst. D 2001, 57, 628-634.

45. Okada, T.; Tanaka, K.; Shiro, M.; Shionoya, M. Heterogeneous assembly of silver (I) and calcium(II) ions accompanyinga dimer formation of cyclo(L-Ala-L-Met) $)_{3}$ isolation. Chem. Commum. 2005, 1484-1486.

46. Li, L.; Zhan, H.; Duan, P.; Liao, J.; Quan, J.; Hu, Y.; Chen, Z.; Zhu, J.; Liu, M.; Wu, Y.-D.; et al. Self-assembling nanotubes consisting of rigid cyclic $\gamma$-peptides. Adv. Funct. Mater. 2012, 22, 3051-3056.

47. Miyazawa, T.; Ogura, M.; Nakajo, S.; Yamada, T. Synthesis of monoesters of $N$-protected $\alpha$-aminocarboxylic acids via the microbial protease-catalyzed regioselective hydrolysis of their diesters. Biotechnol. Tech. 1998, 12, 431-434.

48. Cheng, C.-T.; Lo, V.; Chen, J.; Chen, W.-C.; Lin, C.-Y.; Lin, H.-C.; Yang, C.-H.; Sheh, L. Synthesis and DNA nicking studies of a novel cyclic peptide: cyclo[Lys-Trp-Lys-Ahx-]. Bioorg. Med. Chem. 2001, 9, 1493-1498.

Sample Availability: Samples of the compounds $\mathbf{1}$ and $\mathbf{2}$ are available from the authors.

(C) 2013 by the authors; licensee MDPI, Basel, Switzerland. This article is an open access article distributed under the terms and conditions of the Creative Commons Attribution license (http://creativecommons.org/licenses/by/3.0/). 